\title{
The global distribution of CCR5 delta 32 polymorphism: role in HIV-1 protection
}

\author{
Anuroopa Gupta*, Harish Padh \\ From First International Science Symposium on HIV and Infectious Diseases (HIV SCIENCE 2012) \\ Chennai, India. 20-22 January 2012
}

\section{Background}

The human immunodeficiency virus type 1 (HIV-1) infection occurs by binding to CD4+ receptor and chemokine receptor 5 (CCR5) or the CXC chemokine receptor (CXCR4). A mutation in the CCR5 gene, 32 base pair deletion consequences a truncated protein that is not expressed on the cell surface. The deletion confers resistance to HIV-1 infection and slows the progression of AIDS in HIV infected individuals. The worldwide distribution of CCR5delta 32 polymorphism was congregated by retrieving the data from literature and genotyping new population samples. A comprehensive resource of frequency data for CCR5delta 32 polymorphism in different population samples was created.

\section{Methods}

The data for different populations was obtained from literature. In order to investigate the genetic variation in CCR5 gene in new population, we analyzed 257 healthy control individuals. We examined the CCR 532 base pair deletion (CCR5- $\triangle 32)$ by conventional polymerase chain reaction (PCR).

\section{Results}

The genotype frequency distribution of CCR5 in new population was found to be (CCR5 / CCR5: 98\%, CCR5 / CCR5- $\triangle 32: 2 \%$ and CCR5- $\Delta 32$ / CCR5- $\Delta 32: 0 \%$ ) in healthy control.

\section{Conclusion}

The allele frequency of CCR5- $\Delta 32$ observed for new population is $1 \%$ which is compared with the other populations. The polymorphism CCR $5-\Delta 32$ is primarily found in European population. Compared to our data,

\footnotetext{
* Correspondence: anuroopagupta@gmail.com

Department of Cellular and Molecular Biology, B. V. Patel Pharmaceutical

Education \& Research Development (PERD) Centre, Ahmedabad, India
}

frequency of delta 32 deletion is observed at high frequency in European populations. Our data of delta 32 deletion is significantly different from Caucasians $(\mathrm{p}<0.00000001)$, Africans $(\mathrm{p}<0.01458)$ and Europeans $(\mathrm{p}<0.00000001)$.

Published: 4 May 2012

doi:10.1186/1471-2334-12-S1-016

Cite this article as: Gupta and Padh: The global distribution of CCR5 delta 32 polymorphism: role in HIV-1 protection. BMC Infectious Diseases 2012 12(Suppl 1):O16.
Submit your next manuscript to BioMed Central and take full advantage of:

- Convenient online submission

- Thorough peer review

- No space constraints or color figure charges

- Immediate publication on acceptance

- Inclusion in PubMed, CAS, Scopus and Google Scholar

- Research which is freely available for redistribution

Submit your manuscript at www.biomedcentral.com/submit

\section{() Biomed Central}

\section{(Ciomed Central}

